\title{
Analisa Investasi Perumahan Kalianget Paradise di Kabupaten Sumenep Ditinjau dari Aspek Finansial
}

\author{
Erwin Ready, Cahyono Bintang Nurcahyo, dan Christiono Utomo \\ Departemen Teknik Sipil, Fakultas Teknik Sipil dan Perencanaan, Institut Teknologi Sepuluh Nopember (ITS) \\ e-mail: bintang@ce.its.ac.id
}

\begin{abstract}
Abstrak-Pertambahan jumlah penduduk yang sangat pesat dan semakin meningkatnya taraf hidup akan mengakibatkan kebutuhan rumah tinggal juga semakin meningkat. Salah satu cara memenuhi kebutuhan rumah tinggal adalah dengan membangun sebuah perumahan. Pembangunan perumahan harus memenuhi kelayakan secara finansial dan harus juga sesuai dengan peraturan-peraturan daerah. Paper ini bertujuan menganalisa kelayakan investasi proyek pembangunan Perumahan Kalianget Paradise dari segi finansial, dengan kriteria kelayakan investasi Net Present Value (NPV), Internal Rate of Return (IRR), dan Payback Period (PP) kemudian diuji tingkat sensitivitasnya untuk mengetahui nilai dampak berbagai perubahan dari variabelvariabel penting terhadap hasil yang memungkinkan. Berdasarkan dari hasil perhitungan analisa investasi dengan masa investasi 6 tahun didapatkan nlai Net Present Value (NPV) sebesar Rp 5.854.678.693 (NPV>0), Internal Rate of Return (IRR) diperoleh nilai 47,89\% (IRR>MARR), Payback Period (PP) pada tahun ke 3 bulan ke 2 lebih kecil dari masa investasi 6 tahun, dan dari hasil analisa sensitivitas diketahui bahwa investasi Perumahan Kalianget Paradise akan tetap layak jika kenaikan biaya investasi kurang dari 22,43\%, penurunan tingkat unit terjual (occupancy rate) tidak lebih dari $18,87 \%$, penurunan tingkat harga jual tidak lebih dari $15,87 \%$, dan kenaikan suku bunga pinjaman kurang dari $189,88 \%$.
\end{abstract}

Kata Kunci- Kelayakan finansial, Perumahan, Investasi.

\section{PENDAHULUAN}

$\mathrm{S}$ EIRING dengan pertambahan jumlah penduduk yang sangat pesat dan semakin meningkatnya taraf hidup, akan mengakibatkan kebutuhan rumah tinggal juga semakin meningkat. Bagi masyarakat ekonomi menengah ke atas, hunian menjadi sebuah tuntutan yang sangat penting. Lokasi perumahan yang sempurna dan strategis juga menjadi salah satu pertimbangan untuk memilih tempat tinggal. Begitu juga dengan lingkungan perumahan yang diharapkan adalah perumahan yang lengkap dengan fasilitas-fasilitas penunjang, diantaranya adalah sarana pendidikan, sarana ibadah, sarana berbelanja, sarana olahraga, dan sarana bermain.

Sumenep adalah kota dan kabupaten yang sedang berkembang dengan luas 2.093,46 km2 dan jumlah penduduk 1.014.915 jiwa pada tahun 2010 dengan laju pertumbuhan penduduk $0,55 \%$ [1]. Dan perkembangan properti di Sumenep terus meningkat khususnya rumah tinggal mengakibatkan permintaan akan tanah mengalami peningkatan, sehingga harga tanah di Sumenep juga menjadi semakin tinggi. Hal inilah yang membuat para pengembang mulai beralih ke lahan yang terletak di pinggiran Kabupaten Sumenep agar dapat memenuhi kebutuhan masyarakat akan perumahan.

Agar dapat memenuhi permintaan ini sebuah Developer perumahan Sumenep akan mengembangkan pembangunan Perumahan "Kalianget Paradise" di Sumenep yang letaknya dekat dengan Pelabuhan Kalianget dan Bandara Trunojoyo. Disini Developer berharap dengan mengembangkan perumahan di antara kawasan Pelabuhan dan Bandara akan menarik minat banyak pembeli.

Proyek Investasi Perumahan ini memerlukan dana yang cukup besar, oleh karena itu perlu dilakukan analisa investasi dengan hati-hati agar dana yang telah diinvestasikan pada Perumahan ini kembali disertai tingkat keuntungan [2].

Studi yang digunakan dalam kelayakan investasi suatu proyek adalah aspek finansial. Analisa aspek finansial disini dimaksudkan untuk memilih dan menyaring macam proyek atau investasi yang memiliki potensi keberhasilan paling besar. Kemudian dari aspek finansial yang didapat perlu dilakukan analisa sensitivitas untuk mengetahui seberapa besar pengaruh kelayakan investasi terhadap pengaruh inflasi [3].

\section{PENELITIAN TERDAHULU}

Kegunaan pembahasan penelitian terdahulu di sini adalah untuk menjaga keorisinalitasan dan sebagai relevansi pada topik penelitian ini. Peneliti telah melakukan kajian pustaka terhadap beberapa tulisan yang sudah ada sebelumnya. Berikut penelitian terdahulu dari beberapa sumber:

1. Prastiwi dan Utomo (2013) melakukan penelitian berjudul Studi Kelayakan Investasi Perumahan Green Semanggi Mangrove Ditinjau Dari Aspek Finansial. Penilitian ini bertujuan mengetahui kelayakan proyek Perumahan Green Semanggi Manggrove terhadap finansial. Parameter yang digunakan NPV, IRR, dan PI dan menganalisa sensitivitas dengan merubah perubahan biaya investasi, perubahan tingkat suku bunga dan perubahan pendapatan tahunan [4].

2. Nurfaili dan Utomo (2014) melakukan penelitian berjudul Analisa Investasi Hotel Pesona Makasar. Penelitian ini bertujuan mengetahui kelayakan finansial proyek Hotel Pesona. Parameter yang digunakan NPV, IRR, PI dan menganalisa sensitivitas dengan merubah tingkat hunian (okupansi) dan tarif sewa ruangan [5].

3. Syahrizal dan Utomo (2014) melakukan penelitian berjudul Analisa Pembiayaan Investasi Proyek Perumahan Green Pakis Regency Malang. Penelitian ini bertujuan menentukan bentuk pembiayaan yang paling ringan dan tingkat pengembalian yang paling ringan [6]. 
Persamaan dengan penelitian sebelumnya antara lain sebagai berikut:

1. Objek yang digunakan adalah perumahan.

2. Menganalisa berdasarkan aspek finansial.

Hal-hal yang membedakan dengan penelitian sebelumya antara lain:

1. Objek penelitian berada di Sumenep.

2. Semua tipe rumah dan Site plan di lokasi Perumahan Kalianget Paradise di Kabupaten Sumenep.

\section{METODOLOGI PENELITIAN}

\section{A. Identivikasi Variabel Penelitian}

Variabel yang akan digunakan pada penelitian ini dapat dilihat pada Tabel 1 Variabel Penelitian.

Tabel 1.

Variabel penelitian

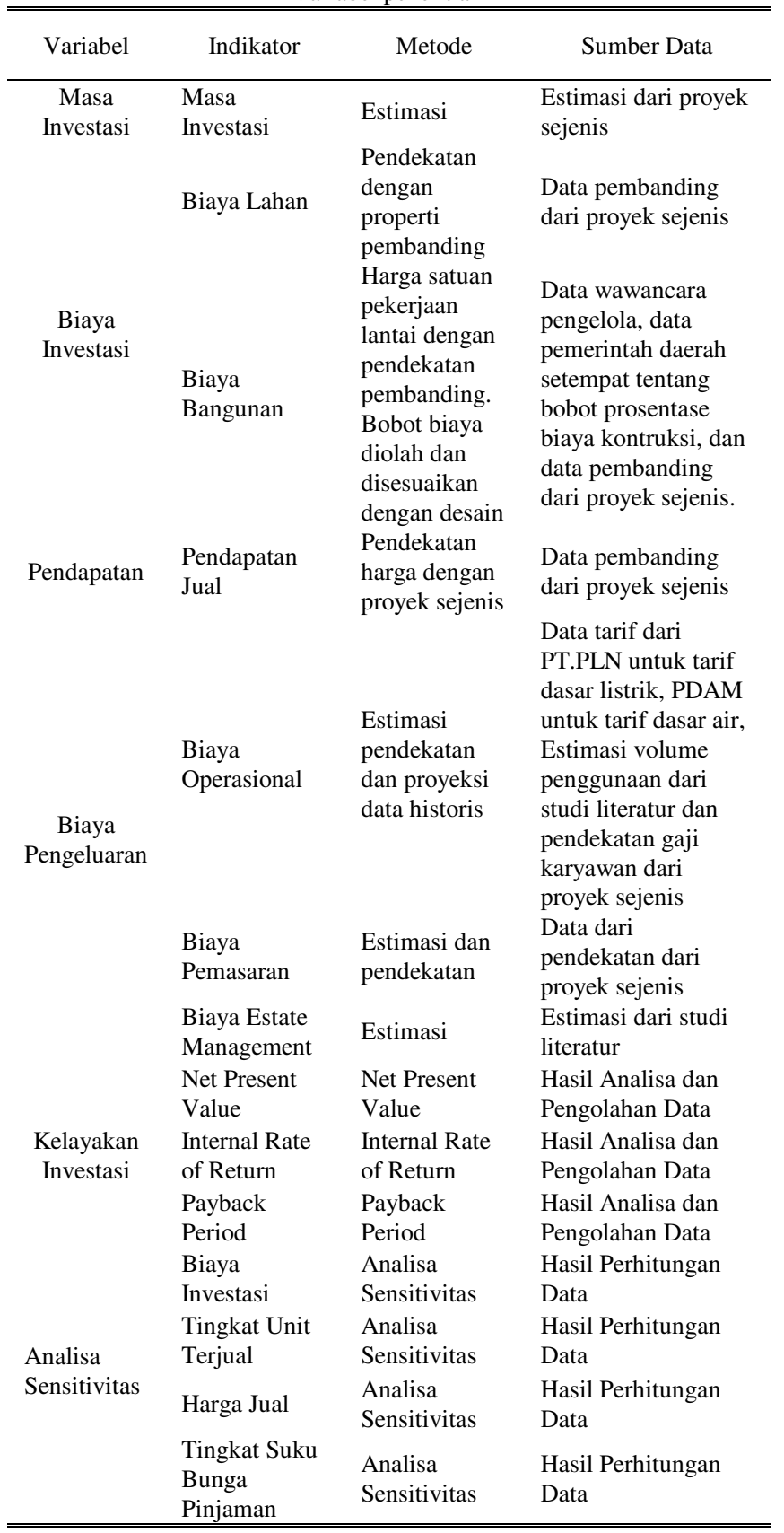

Sumber: Analisa Penulisan

\section{B. Metode Perhitungan}

Langkah berikutnya setelah tahap analisa adalah perhitungan yang meliputi:

1. Analisa Kelayakan Investasi

Dari analisa yang sudah dilakukan sebelumnya yaitu siklus bisnis, bisa didapatkan kelayakan investasi Perumahan Kalianget Paradise Sumenep dengan menghitung:

a) Net Present Value (NPV)

Adalah metode yang menghitung selisih antara nilai investasi dengan nilai penerimaan-penerimaan kas bersih (operasional maupun terminal cash flow) di masa yang akan datang [3].

$$
\mathrm{NPV}=-k t+\frac{b_{1}+c_{1}}{(1+i)}+\frac{b_{2}+c_{2}}{(1+i)^{2}}+\cdots+\frac{b_{n}+c_{n}}{(1+i)^{n}}
$$

Dimana:

$$
\begin{aligned}
& \text { NPV = Nilai sekarang bersih } \\
& \mathrm{Kt}=\text { Merupakan capital yang digunakan pada } \\
& \text { periode investasi }
\end{aligned}
$$

Merupakan tingkat bunga yang menggambarkan bahwa antara benefit (penerimaan) yang telah present-valuekan dan cost (pengeluaran) yang telah di present value kan sama dengan nol [3]

$$
I R R=\sum_{t=0}^{n} \frac{(C) t}{(1+i)^{t}}-\sum_{t=0}^{n} \frac{(C o) t}{(1+i)^{t}}
$$

Dimana:

IRR = Arus pengembalian internal

(C) $\mathrm{t}=$ Aliran kas masuk tahun ke- $\mathrm{t}$

(Co)t $\mathrm{t}$ Aliran kas keluar tahun ke- $\mathrm{t}$

$\mathrm{n} \quad=$ Umur investasi

$\mathrm{i}=$ Discount Rate

$\mathrm{t} \quad=$ Tahun

c) Payback Period (PP)

Merupakan jangka waktu yang diperlukan untuk membayar kembali (mengembalikan) semua biaya-biaya yang telah dikeluarkan didalam investasi suatu proyek [3].

$$
\text { Payback Period }=\frac{l}{A b}
$$

1 = Besarnya biaya investasi yang diperlukan

$\mathrm{Ab}=$ Keuntungan bersih yang diperoleh tiap tahunnya

\section{HASIL DAN PEMBAHASAN}

\section{A. Konsep Pengembangan Perumahan}

Proyek Perumahan "Kalianget Paradise" dibangun di atas lahan seluas 29.410 m2 (2,941 HA) yang terletak di Jl. Raya Kalianget, Sumenep. Proyek Perumahan ini memiliki 222 unit rumah yang terdiri dari dua tipe unit yaitu Tipe 36 dan Tipe 54. Tipe 36 terdiri dari 145 unit rumah dengan luas tanah minimal $72 \mathrm{~m} 2$. Sedangkan untuk Tipe 54 terdiri dari 77 unit rumah dengan luas minimal $84 \mathrm{~m} 2$. 
Pengembangan Perumahan akan dimulai dibangun pada tahun 2017 dan ditargetkan rampung pada tahun 2020. Konsep pengembangan pada perumahan direncanakan menjadi 7 tahap yaitu tahap pertama pada tahun ke 0 , tahap kedua tahun ke 1 , tahap ketiga pada tahun 2, tahap keempat pada tahun 3, tahap kelima pada tahun ke 4, dan ditambah 2 tahun untuk tahap perawatan perumahan (Estate Management). Rincian konsep pengembangan yaitu sebagai berikut, dan bisa dilihat pada Tabel 2 :

Tabel 2.

Tahap pengembangan perumahan

\begin{tabular}{|c|c|c|c|c|c|}
\hline \multirow{2}{*}{$\begin{array}{l}\mathrm{N} \\
\mathrm{o}\end{array}$} & \multirow{2}{*}{ Keterangan } & \multicolumn{4}{|c|}{ Tahun } \\
\hline & & 2017 & 2018 & 2019 & 2020 \\
\hline 1 & Tahapan & 2 & 3 & 4 & 5 \\
\hline 2 & Block & A, B, C & $\begin{array}{c}\mathrm{D}, \mathrm{E}, \mathrm{F}, \\
\mathrm{G}\end{array}$ & $\begin{array}{c}\mathrm{H}, \mathrm{I}, \mathrm{J}, \mathrm{K}, \\
\mathrm{L}\end{array}$ & $\mathrm{M}, \mathrm{N}, \mathrm{O}$ \\
\hline 3 & Luasan & $\begin{array}{l}5922,2 \\
7\end{array}$ & 6624,00 & 9303,79 & 7559,41 \\
\hline 4 & Prosentase & $20 \%$ & $23 \%$ & $32 \%$ & $26 \%$ \\
\hline \multirow[t]{4}{*}{5} & Type $36 / 72$ & & & & \\
\hline & Unit & 40 & 68 & 31 & 6 \\
\hline & Luasan & 2880 & 4896 & 2261,46 & 432 \\
\hline & Kelebihan Tanah & 0 & 0 & 29,46 & 0 \\
\hline \multirow[t]{4}{*}{6} & Type 54/84 & & & & \\
\hline & Unit & 3 & 0 & 32 & 42 \\
\hline & Luasan & 337,86 & 0 & 3620,45 & 4396,35 \\
\hline & Kelebihan Tanah & 85,86 & 0 & 932,45 & 868,35 \\
\hline 7 & $\begin{array}{c}\text { Jalan Paving dan } \\
\text { Drainase }\end{array}$ & $\begin{array}{c}2704,4 \\
1\end{array}$ & 1728,00 & 3239,86 & 1354,84 \\
\hline 8 & $\begin{array}{c}\text { Area } \\
\text { Penghijauan/Taman }\end{array}$ & 0 & 0 & 182 & 1376,22 \\
\hline
\end{tabular}

\section{Tahap Pertama (Tahun $\mathrm{Ke}-0$ )}

Tahap pertama pembelian lahan dan pematangan lahan seluas $\pm 2,941$ hektar. Harga tanah didapat dari hasil estimasi pembanding terhadap lahan yang telah terjual disekitar lokasi.

2. Tahap Kedua (Tahun $\mathrm{Ke}-1$ )

Tahap kedua adalah tahap pembangunan unit rumah block A, B dan C serta pembangunan infrastruktur tahap 1 seperti jalan aspal dan saluran drainase.

3. Tahap Ketiga (Tahun $\mathrm{Ke}-2$ )

Tahap pembangunan unit rumah block D, E, F dan $G$ serta pembangunan infrastruktur tahap 2 seperti jalan aspal dan saluran drainase.

4. Tahap Keempat (Tahun $\mathrm{Ke}-3$ )

Tahap pembangunan unit rumah block $\mathrm{H}, \mathrm{I}, \mathrm{J}, \mathrm{K}$ dan $\mathrm{L}$ serta pembangunan infrastruktur tahap 3 seperti jalan aspal, saluran drainase dan taman.

5. Tahap Kelima (Tahun $\mathrm{Ke}-4$ )

Tahap pembangunan unit rumah block $\mathrm{M}, \mathrm{N}$, dan $\mathrm{O}$ serta pembangunan infrastruktur tahap 4 seperti jalan aspal, saluran drainase dan taman.

6. Tahap Keenam (Tahun $\mathrm{Ke}-5$ )

Tahap keenam adalah tahap perawatan dan pengelolaan perumahan setelah unit rumah sudah terbangun seluruhnya.

7. Tahap Ketujuh (Tahun Ke - 6)

Tahap ketujuh adalah tahap terakhir perawatan dan pengelolaan perumahan setelah unit rumah sudah terbangun seluruhnya.

\section{B. Analisa Investasi}

Biaya investasi Kalianget Paradise dikeluarkan diawal pengembangan perumahan. Dalam melakukan analisa biaya investasi perumahan ini dilakukan dengan pendekatanpendekatan harga pasar. Jenis biaya tersebut diantaranya:

1. Biaya Lahan/Tanah.

Untuk menentukan nilai pasar tanah dari objek penelitian dengan cara dibandingkan dengan harga tanah masingmasing properti pembanding. Data yang dibandingkan meliputi waktu transaksi, letak lokasi terhadap fasilitas, lebar jalan, bentuk tanah, peruntukan tanah, surat tanah, elevasi tanah, dan lingkungan.

Dari perhitungan berdasarkan penyesuaian dengan pembanding didapatkan biaya tanah untuk pembangunan perumahan Kalianget Paradise Rp 3.676.250.000.

2. Biaya Kontruksi.

a. Biaya Pematangan Lahan

Biaya pematangan lahan dilakukan apabila memerlukan cut and fill. Dari lahan yang direncanakan diketahui jenis lahan eksisting di kalianget paradise berupa lahan kosong, didapat beda tinggi lahan terhadap permukaan jalan sekitar 0,5 m maka membutuhkan aktivitas pematangan lahan dengan pengurungan. Pematangan lahan yang dibutuhkan pada Perumahan Kalianget Paradise adalah serupa dengan yang dilakukan oleh developer Perumahan Agung Residence Babbalan, sehingga detail item pekerjaan dan harga satuan menggunakan data dari developer Agung Residence Babbalan. Kemudian dikalikan dengan volume pekerjaan yang dibutuhkan di Perumahan Kalianget Paradise. Dari luas lahan $29.410 \mathrm{~m} 2$ dengan pengurugan setinggi $0,5 \mathrm{~m}$ diketahui biaya yang dibutuhkan Rp 1.506.957.500.

b. Biaya Bangunan

Biaya bangunan dihitung dengan pendekatan biaya bangunan proyek sejenis di daerah Kabupaten Sumenep. Data yang dibandingkan meliputi spesifikasi bangunannya. Proyek sejenis yang akan digunakan sebagai pembanding adalah Perumahan Agung Residence Babbalan untuk tipe 36 dengan biaya bangunan Rp 75.570.000 dan Perumahan Griya Alam Raya C1 untuk tipe 52 dengan biaya bangunan Rp 143.441.633.

Dari hasil pembanding biaya bangunan diperoleh biaya bangunan/m2 untuk masing-masing tipe rumah. Untuk tipe proyek ini dipakai biaya bangunan/m2 dari Perumahan “Agung Residence Babbalan” sebesar Rp 2.099.167 karena mengacu pada spesifikasi bangunan yang hampir sama dengan objek penilitian.

Dalam analisa biaya bangunan dilakukan secara bertahap sesuai tahapan rencana pengembangan perumahan, dan berdasarkan interview dengan pihak developer diasumsikan biaya bangunan akan naik sebesar $10 \%$ setiap tahunnya. Perhitungan biaya bangunan per-tahun dapat dilihat pada tabel 3.

Tabel 3.

Perhitungan Biaya Bangunan Per-Tahun

\begin{tabular}{|c|c|c|c|c|c|c|c|c|c|c|}
\hline \multirow{2}{*}{ Tahun } & \multirow{2}{*}{ Block } & \multirow{2}{*}{$\mathrm{Harga} / \mathrm{m}^{2}$} & \multicolumn{3}{|c|}{ Type rumah 36} & \multicolumn{3}{|c|}{ Type rumah 54} & \multirow{2}{*}{\multicolumn{2}{|c|}{ Total Biaya }} \\
\hline & & & Unit & & Biaya & Unit & & Biaya & & \\
\hline 2017 & $\mathrm{~A}, \mathrm{~B}, \mathrm{C}$ & Rp 2.099.167 & 40 & $\mathrm{Rp}$ & 3.022 .800 .000 & 3 & $\mathrm{Rp}$ & 340.065 .000 & $\mathrm{Rp}$ & 3.362 .865 .000 \\
\hline 2018 & $\mathrm{D}, \mathrm{E}, \mathrm{F}, \mathrm{G}$ & Rp 2.309.083 & 68 & $\mathrm{Rp}$ & 5.652 .636 .000 & 0 & $\mathrm{Rp}$ & & $\mathrm{Rp}$ & 5.652 .636 .000 \\
\hline 2019 & $\mathrm{H}, \mathrm{I}, \mathrm{J}, \mathrm{K}$ & Rp 2.539.992 & 31 & $\mathrm{Rp}$ & 2.834 .630 .700 & 32 & $\mathrm{Rp}$ & 4.389 .105 .600 & $\mathrm{Rp}$ & 7.223 .736 .300 \\
\hline \multirow[t]{2}{*}{2020} & $\mathrm{~L}, \mathrm{M}, \mathrm{N}$ & Rp 2.793.991 & 6 & $\mathrm{Rp}$ & 603.502.020 & 42 & $\mathrm{Rp}$ & 6.336 .771 .210 & $\mathrm{Rp}$ & 6.940 .273 .230 \\
\hline & Total & & 145 & Rp 1 & 10.957 .650 .000 & 77 & $\mathrm{Rp}$ & 8.728 .335 .000 & $\mathrm{Rp}$ & 23.179 .510 .530 \\
\hline
\end{tabular}

Sumber: Hasil Olahan Penulis 


\section{Biaya Pengembangan Tapak dan Infrastruktur.}

Biaya infrastruktur dan fasilitas diperhitungkan sesuai infrastruktur yang terpasang di lapangan atau pada tahapan yang direncanakan seperti jalan aspal, saluran drainase, taman/ruang terbuka hijau, dan penerangan jalan umum.

Pembangunan infrastruktur dan fasilitas yang dibutuhkan pada Perumahan Kalianget Paradise adalah serupa dengan yang dilakukan oleh developer Perumahan Agung Residence Babbalan, sehingga detail item pekerjaan dan harga satuan menggunakan data dari developer Agung Residence Babbalan. Kemudian dikalikan dengan volume pekerjaan yang dibutuhkan di Perumahan Kalianget Paradise.

Pembangunan infrastruktur mempunyai beberapa tahapan sesuai konsep pengembangannya dimulai dari tahun 2017 sampai dengan 2020, maka diasumsikan biaya mengalami kenaikan sebesar $10 \%$ setiap tahunnya

Rekapitulasi perhitungan biaya infrastruktur dan fasilitas yang terdiri dari penjumlahan biaya jalan aspal, saluran drainase, taman/ruang terbuka hijau, dan penerangan jalan umum dapat dilihat pada Tabel 4.

Tabel 4.

Rekapitulasi Biaya Infrastrukur dan Fasilitas

\begin{tabular}{|c|c|c|c|c|}
\hline $\begin{array}{c}\text { Uraian } \\
\text { Pekerjaan }\end{array}$ & $\begin{array}{c}2017 \\
\text { Tahun ke-1 }\end{array}$ & $\begin{array}{c}2018 \\
\text { Tahun ke-2 }\end{array}$ & $\begin{array}{c}2019 \\
\text { Tahun ke-3 }\end{array}$ & $\begin{array}{c}2020 \\
\text { Tahun ke-4 }\end{array}$ \\
\hline Jalan Paving & Rp 331.738 .347 & Rp 233.163.231 & $\mathrm{Rp} 480.878 .162$ & Rp 250.921.709 \\
\hline $\begin{array}{l}\text { Saluran } \\
\text { Drainase }\end{array}$ & Rp 212.918.070 & Rp 149.650 .065 & Rp 308.639.779 & Rp 161.047.906 \\
\hline $\begin{array}{l}\text { Taman/Ruang } \\
\text { Terbuka Hijau }\end{array}$ & $\mathrm{Rp}$ & $\mathrm{Rp}$ & 3.015 .318 & Rp $\quad 21.760 .509$ \\
\hline $\begin{array}{l}\text { Penerangan } \\
\text { Jalan Umum }\end{array}$ & Rp $\quad 30.000 .000$ & Rp $\quad 20.900 .000$ & $\mathrm{Rp} \quad 43.560 .000$ & $\mathrm{Rp} \quad 22.627 .000$ \\
\hline Total & Rp 574.656.418 & Rp 403.713.296 & Rp 836.093.258 & Rp 456.357.123 \\
\hline
\end{tabular}

Sumber: Hasil Olahan Penulis

\section{Biaya Jasa Profesi.}

Biaya jasa profesi diperhitungkan berdasarkan asumsi sebesar 3\% dari biaya bangunan per-tahunnya (Buku Juwana, 2005).

5. Biaya Administrasi.

Biaya administrasi diperhitungkan berdasarkan asumsi sebesar 2\% dari biaya bangunan per-tahunnya (Buku Juwana, 2005).

6. Biaya Lain-Lain.

Biaya lain-lain diperhitungkan berdasarkan asumsi sebesar 5\% dari biaya bangunan per-tahunnya (Buku Juwana, 2005).

\section{Biaya Investasi Total}

Biaya investasi total diperoleh dari penjumlahan biaya lahan, biaya bangunan, biaya pengembangan tapak dan infrastruktur, biaya jasa profesi, biaya administrasi, biaya lain-lain. Rekapitulasi perhitungan biaya investasi total dapat dilihat pada Tabel 5.

Tabel 5.

Rekapitulasi Perhitungan Biaya Investasi

\begin{tabular}{|c|c|c|c|c|c|c|}
\hline No & $\begin{array}{c}\text { Uraian } \\
\text { Pekerjaan }\end{array}$ & $\begin{array}{c}2016 \\
\text { Tahun ke-0 }\end{array}$ & $\begin{array}{c}2017 \\
\text { Tahun ke-1 }\end{array}$ & $\begin{array}{c}2018 \\
\text { Tahun ke-2 }\end{array}$ & $\begin{array}{c}2019 \\
\text { Tahun ke-3 }\end{array}$ & $\begin{array}{c}2020 \\
\text { Tahun ke-4 }\end{array}$ \\
\hline 1 & Biaya Lahan & $\begin{array}{l}\mathrm{Rp} \\
3.676 .250 .000\end{array}$ & & & & \\
\hline 2 & Biaya Kontruksi & $\begin{array}{l}\mathrm{Rp} \\
1.506 .957 .500\end{array}$ & $\begin{array}{l}\mathrm{Rp} \\
3.362 .865 .000\end{array}$ & $\begin{array}{l}\mathrm{Rp} \\
5.652 .636 .000\end{array}$ & $\begin{array}{l}\mathrm{Rp} \\
7.223 .736 .300\end{array}$ & $\begin{array}{l}\mathrm{Rp} \\
6.940 .273 .230\end{array}$ \\
\hline 3 & $\begin{array}{l}\text { Biaya } \\
\text { Infrastruktur }\end{array}$ & & $\begin{array}{l}\mathrm{Rp} \\
574.656 .418\end{array}$ & $\begin{array}{l}\mathrm{Rp} \\
403.713 .296\end{array}$ & $\begin{array}{l}\mathrm{Rp} \\
836.093 .258\end{array}$ & $\begin{array}{l}\mathrm{Rp} \\
456.357 .123\end{array}$ \\
\hline 4 & $\begin{array}{l}\text { Jasa Profesi (3\% } \\
\text { dari Biaya } \\
\text { Bangunan) }\end{array}$ & & $\begin{array}{l}\mathrm{Rp} \\
100.885 .950\end{array}$ & $\begin{array}{l}\mathrm{Rp} \\
169.579 .080\end{array}$ & $\begin{array}{l}\mathrm{Rp} \\
216.712 .089\end{array}$ & $\begin{array}{l}\mathrm{Rp} \\
208.208 .197\end{array}$ \\
\hline 5 & $\begin{array}{l}\text { Administrasi } \\
\text { (2\% dari Biaya } \\
\text { Bangunan) }\end{array}$ & & $\begin{array}{l}\mathrm{Rp} \\
67.257 .300\end{array}$ & $\begin{array}{l}\mathrm{Rp} \\
113.052 .720\end{array}$ & $\begin{array}{l}\mathrm{Rp} \\
144.474 .726\end{array}$ & $\begin{array}{l}\mathrm{Rp} \\
138.805 .465\end{array}$ \\
\hline 6 & $\begin{array}{l}\text { Biaya Lain -Lain } \\
\text { (5\% dari Biaya } \\
\text { Bangunan) }\end{array}$ & & $\begin{array}{l}\mathrm{Rp} \\
168.143 .250\end{array}$ & $\begin{array}{l}\mathrm{Rp} \\
282.631 .800\end{array}$ & $\begin{array}{l}\mathrm{Rp} \\
361.186 .815\end{array}$ & $\begin{array}{l}\mathrm{Rp} \\
347.013 .662\end{array}$ \\
\hline
\end{tabular}

\begin{tabular}{clllll} 
Total & $\mathrm{Rp}$ & $\mathrm{Rp}$ & $\mathrm{Rp}$ & $\mathrm{Rp}$ & $\mathrm{Rp}$ \\
& 5.183 .207 .500 & 4.273 .807 .918 & 6.621 .612 .896 & 8.782 .203 .188 & 8.090 .657 .676 \\
\hline \hline Sumber: Hasil Olahan Penulis & & & &
\end{tabular}

\section{Analisa Pendapatan}

Pendapatan Perumahan Kalianget Paradise diperoleh dari penjualan unit rumah yang akan direncanakan terjual habis pada tahun ke-4. Perumahan ini memiliki dua harga yang berbeda sesuai dengan type rumah yang akan di jual. Harga unit rumah sudah termasuk biaya rumah dan tanah, izin mendirikan bangunan (IMB), pemasangan instalasi (PLN, PDAM), dan serta SHGB (Surat Hak Guna Bangunan).

Tabel 6.

Rencana Penjualan

\begin{tabular}{ccccccc}
\multicolumn{7}{c}{ Rencana Penjualan } \\
\hline \hline Rencana & 201 & 201 & 201 & 202 & 202 & 202 \\
Penjualan & 7 & 8 & 9 & 0 & 1 & 2 \\
\hline Tahap 1 & & & & & & \\
1. Type 36 & 20 & 10 & 10 & & & \\
2. Type 54 & 1 & 1 & 1 & & & \\
Tahap 2 & & & & & & \\
1. Type 36 & & 34 & 17 & 17 & & \\
2. Type 54 & & 0 & 0 & 0 & & \\
Tahap 3 & & & & & & \\
1. Type 36 & & & 15 & 8 & 8 & \\
2. Type 54 & & & 16 & 8 & 8 & \\
Tahap 4 & & & & & & \\
1. Type 36 & & & & 3 & 2 & 1 \\
2. Type 54 & & & & 21 & 11 & 10 \\
Total & 21 & 45 & 59 & 57 & 29 & 11 \\
\hline \hline
\end{tabular}

Sumber: Hasil Olahan Penulis

Tabel 7. Rekapitulasi Pendapatan

\begin{tabular}{clllllll}
\multicolumn{7}{c}{ Rekapitulasi Pendapatan } \\
\hline \hline Pendapatan & \multicolumn{2}{c}{$\mathbf{2 0 1 7}$} & \multicolumn{2}{c}{$\mathbf{2 0 1 8}$} & \multicolumn{2}{c}{$\mathbf{2 0 1 9}$} & \multicolumn{2}{c}{$\mathbf{2 0 2 0}$} & \multicolumn{2}{c}{$\mathbf{2 0 2 1}$} & \multirow{2}{*}{$\mathbf{2 0 2 2}$} \\
\hline Pembangunan & $\mathrm{Rp}$ & $\mathrm{Rp}$ & $\mathrm{Rp}$ & & & \\
Tahap 1 & 2.707 .563 .968 & 1.633 .788 .259 & 1.811 .048 .110 & & & \\
Pembangunan & & $\mathrm{Rp}$ & $\mathrm{Rp}$ & $\mathrm{Rp}$ & & \\
Tahap 2 & & 4.506 .700 .000 & 2.478 .685 .000 & 2.726 .553 .500 & & \\
Pembangunan & & & $\mathrm{Rp}$ & $\mathrm{Rp}$ & $\mathrm{Rp}$ & \\
Tahap 3 & & & 7.643 .314 .306 & 4.413 .679 .425 & 5.010 .692 .440 & \\
Pembangunan & & & & $\mathrm{Rp}$ & $\mathrm{Rp}$ & $\mathrm{Rp}$ \\
Tahap 4 & & & & 8.499 .367 .413 & 4.893 .686 .810 & 4.270 .451 .323 \\
Total & $\mathrm{Rp}$ & $\mathrm{Rp}$ & $\mathrm{Rp}$ & $\mathrm{Rp}$ & $\mathrm{Rp}$ & $\mathrm{Rp}$ \\
& 2.707 .563 .968 & 6.140 .488 .259 & 11.933 .047 .41615 .639 .600 .338 & 9.904 .379 .250 & 4.270 .451 .323 \\
\hline \hline
\end{tabular}

Sumber: Hasil Olahan Penulis

Penjualan unit perumahan dilakukan dengan cara angsuran $30 \%$ sebagai uang muka dan dibayarkan pada tahun awal pengambilan rumah dan sisa angsuran $70 \%$ dilunasi pada tahun berikutnya dengan target tahun ke-6 yang direncanakan semua unit sudah terjual. Untuk rencana penjualan unit perumahan diasumsikan berdasarkan interview yang sudah dilakukan dengan pihak developer, bahwa setiap rencana tahap pembangunan akan terjual 50\% di tahun pertama, $25 \%$ di tahun kedua dan $25 \%$ di tahun ketiga. Sedangkan harga rumah perumahan ini diestimasikan berdasarkan pendekatan harga rumah pembanding perumahan sejenis lainnya. Sehingga didapatkan nilai harga jual rumah type 36 sebesar Rp 120.500.000, nilai harga jual rumah type 54 sebesar Rp 245.000.000 dan diasumsikan harga jual rumah mengalami kenaikan sebesar $10 \%$ setiap tahunnya. Rencana penjualan selengkapnya dapat dilihat pada Tabel 6 dan rekapitulasi pendapatan dari perumahan "Kalianget Paradise" dapat dilihat pada Tabel 7.

\section{E. Biaya Pengeluaran}

Biaya pengeluaran untuk Perumahan Kalianget Paradise terdiri atas: 
1. Biaya Operasional.

Biaya operasional pada perumahan ini yaitu:

a. Perhitungan biaya listrik kantor manajemen dan pemasaran.

b. Perhitungan biaya air kantor manajemen dan pemasaran

c. Perhitungan gaji karyawan pengelola perumahan.

2. Beban Pemasaran.

3. Biaya Estate Management.

\section{F. Rekapitulasi Biaya Pengeluaran}

Dari semua perhitungan yang sudah dijelaskan pada sub bab diatas, kemudian dilakukan rekapitulasi untuk mengetahui total biaya per tahunnya dan untuk menghitung aliran kas. Perhitungan biaya arus keluar dapat dilihat pada Tabel 8.

Tabel 8.

Rekapitulasi Biaya Pengeluaran

\begin{tabular}{ccr}
\hline \hline Tahun & & \multicolumn{1}{r}{ Total Biaya Per Tahun } \\
\hline 1 & $\mathrm{Rp}$ & $331.022 .659,19$ \\
2 & $\mathrm{Rp}$ & $526.211 .700,19$ \\
3 & $\mathrm{Rp}$ & $846.542 .398,67$ \\
4 & $\mathrm{Rp}$ & $1.058 .742 .574,76$ \\
5 & $\mathrm{Rp}$ & $776.770 .588,93$ \\
6 & $\mathrm{Rp}$ & $501.787 .026,05$ \\
\hline \hline
\end{tabular}

Sumber: Hasil Olahan Penulis

\section{G. Sumber Pembiayaan.}

Penetapan sumber pembiayaan (cost of capital) proyek perumahan berdasarkan asumsi yaitu $40 \%$ modal sendiri dan $60 \%$ dari pinjaman bank. Suku bunga yang dipakai yaitu dari rata-rata suku bunga beberapa bank yang ada di Indonesia.

Tabel 9.

Perhitungan Besaran Pinjaman

\begin{tabular}{|c|c|c|c|c|c|c|c|c|}
\hline Tahun & & 3iaya Investasi & & Pinjaman & $\mathrm{i}$ & $\mathrm{n}$ (tahun) & & Pembayaran \\
\hline 2016 & $\mathrm{Rp}$ & 5.183.207.500 & $\mathrm{Rp}$ & 3.109.924.500 & $10,35 \%$ & 2 & $\mathrm{Rp}$ & 1.800 .339 .155 \\
\hline 2017 & $\mathrm{Rp}$ & 4.273 .807 .918 & $\mathrm{Rp}$ & 2.564.284.751 & $10,35 \%$ & 2 & $\mathrm{Rp}$ & 1.484 .467 .627 \\
\hline 2018 & $\mathrm{Rp}$ & 6.621 .612 .896 & $\mathrm{Rp}$ & 3.972 .967 .737 & $10,35 \%$ & 2 & $\mathrm{Rp}$ & 2.299.955.957 \\
\hline 2019 & $\mathrm{Rp}$ & 8.782 .203 .188 & $\mathrm{Rp}$ & 5.269 .321 .913 & $10,35 \%$ & 2 & $\mathrm{Rp}$ & 3.050 .417 .000 \\
\hline 2020 & $\mathrm{Rp}$ & 8.090 .657 .676 & $\mathrm{Rp}$ & 4.854.394.606 & $10,35 \%$ & 2 & $\mathrm{Rp}$ & 2.810 .215 .066 \\
\hline
\end{tabular}

Sumber: Hasil Olahan Penulis

Modal pinjaman bank akan dikenakan bunga sebesar $10,35 \%$ yang akan dibayarkan selama 2 tahun untuk pinjaman dari tahun ke-0 sampai tahun ke-4. Besaran pembayaran pinjaman didapatkan dari perhitungan dapat dilihat pada Tabel 9.

\section{H. Penetapan MARR (Minimum Attractive Rate Of Return)}

Tingkat pengembalian modal (Rate of Return) yang diinginkan untuk modal sendiri diperoleh dari rata-rata suku bunga deposito beberapa bank di indonesia dimana safe rate \pm resiko. Resiko diasumsikan sama dengan nilai safe rate.

Tingkat pengembalian modal pinjaman diperoleh dari rata - rata tingkat suku bunga pinjaman beberapa Bank di Indonesia sebesar $10,35 \%$. Tingkat suku bunga deposito beberapa Bank di Indonesia sebesar 5,84\%.

Untuk menentukan MARR (Minimum Attractive Rate Of Return) investasi dapat dihitung dengan cara sebagai berikut: MARR investasi $=$ (ratio equity $\mathrm{x}$ rate of return equity) + (ratio loan $\mathrm{x}$ rate of return loan) $=(40 \% \times 11,68 \%)+(60 \% \times 10,35 \%)$ $=10,88 \%$

\section{Analisa Kelayakan Investasi}

Perhitungan aliran kas masuk dan aliran kas keluar digunakan untuk membuat cashflow proyek pembangunan perumahan. Penilaian investasi dilakukan untuk masa investasi 6 tahun. Kriteria yang digunakan untuk menilai kelayakan investasi proyek Perumahan Kalianget Paradise dengan menggunakan metode NPV, IRR, dan PP serta dilanjutkan dengan analisa sensitivitas.

Dari hasil perhitungan aliran kas nilai NPV sebesar Rp 5.854.678.693 dengan nilai MARR 10,88\% dan diketahui PP terjadi pada tahun ke-3 bulan ke-2. Kemudian dilakukan perhitungan IRR dengan menggunakan tingkat bunga (i) yang berbeda-beda dan secara coba-coba yang NPVnya bernilai positif dan bernilai negatif. Dari hasil perhitungan didapat nilai IRR sebesar 47,89\% dengan cara interpolasi, jadi nilai IRR > MARR. Dengan demikian investasi proyek Perumahan "Kalianget Paradise" di Kabupaten Sumenep layak untuk dilakukan.

\section{J. Analisa Sensitivitas}

Analisa sensitivitas digunakan untuk mengetahui seberapa besar pengaruh suatu keputusan terhadap perubahan parameter-parameter yang mempengaruhinya. Pada paper ini parameter yang diubah adalah perubahan biaya investasi, perubahan pendapatan tahunan, dan perubahan tingkat suku bunga pinjaman kemudian dilihat hubungan terhadap NPV aliran kas perumahan ini.

1. Perubahan Biaya Investasi

Bila besarnya biaya investasi awal diubah pada interval $\pm 25 \%$ maka nilai-nilai NPV akan menjadi sebagai berikut (Tabel 10):

Tabel 10

Biaya Investasi dengan NPV

\begin{tabular}{lccclrr}
\hline \hline \multicolumn{1}{c}{ Perubahan } & & Biaya Investasi Total & \multicolumn{2}{c}{ NPV } \\
\hline Biaya Investasi Bertambah & $25 \%$ & $\mathrm{Rp}$ & 41.189 .361 .472 & $\mathrm{Rp}(671.894 .725)$ \\
NPV Mendekati 0 & $22,43 \%$ & $\mathrm{Rp}$ & 40.341 .292 .725 & $\mathrm{Rp}$ & 2.860 .578 \\
Biaya Investasi Bertambah & $20 \%$ & $\mathrm{Rp}$ & 39.541 .787 .013 & $\mathrm{Rp}$ & 633.419 .959 \\
Biaya Investasi Awal & $0 \%$ & $\mathrm{Rp}$ & 32.951 .489 .178 & & $\mathrm{Rp} 5.854 .678 .693$ \\
\hline \hline
\end{tabular}

Sumber: Hasil Olahan Penulis

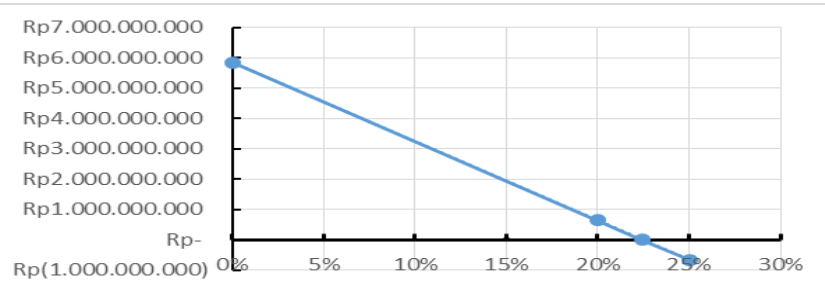

Gambar 1. Grafik Hubungan Perubahan Biaya Investasi Terhadap NPV (Sumber: Olahan Penulis)

Dari Tabel 10 dan Gambar 1 hubungan perubahan biaya investasi terhadap NPV, dapat diketahui batas kenaikan biaya investasi Perumahan Kalianget Paradise yaitu sebesar $22,43 \%$ dari biaya investasi awal.

2. Perubahan Tingkat Unit Terjual (Occupancy Rate)

Bila besarnya awal diubah pada interval $\pm 20 \%$ maka nilainilai NPV akan menjadi sebagai berikut (Tabel 11):

Tabel 11.

Hubungan Penjualan Unit dengan NPV

\begin{tabular}{cccccc}
\hline \hline \multirow{2}{*}{ Perubahan } & \multicolumn{5}{c}{ Jumlah Unit Terjual } \\
Tipe 36 & Tipe 54 & \multirow{2}{*}{ NPV } \\
\hline Rencana Penjualan & $100,00 \%$ & 145 & 77 & $\mathrm{Rp}$ & 5.854 .678 .693 \\
$\begin{array}{c}\text { Unit } \\
\text { Penjualan Unit }\end{array}$ & $85,00 \%$ & 125 & 67 & $\mathrm{Rp}$ & 1.582 .966 .866 \\
$\begin{array}{c}\text { Berkurang 15\% } \\
\text { Penjualan Unit }\end{array}$ & $81,60 \%$ & 117 & 62 & $\mathrm{Rp}$ & $(356.649 .541)$ \\
NPV Mendekati 0 & & & & &
\end{tabular}




\begin{tabular}{cccccc}
\hline \hline $\begin{array}{c}\text { Penjualan Unit } \\
\text { Berkurang 20\% }\end{array}$ & $80,00 \%$ & 116 & 62 & $\mathrm{Rp}$ & (464.717.739) \\
\hline \hline
\end{tabular}

Sumber: Hasil Olahan Penulis

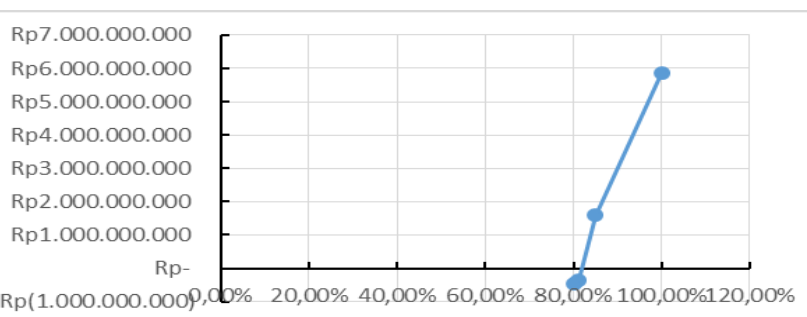

Gambar 2. Grafik Hubungan Perubahan Tingkat Unit Terjual Terhadap NPV (Sumber: Olahan Penulis)

Dari Tabel 11 dan Gambar 2 hubungan perubahan tingkat unit terjual terhadap NPV, dapat diketahui batas penurunan penjualan unit setiap tahun Perumahan Kalianget Paradise yaitu sebesar $-18,87 \%$ dari rencana penjualan unit awal.

3. Perubahan Harga Jual

Bila besarnya harga jual awal diubah pada interval $\pm 20 \%$ maka nilai-nilai NPV akan menjadi sebagai berikut (Tabel 12):

Tabel 12.

Hubungan Harga Jual dengan NPV

\begin{tabular}{|c|c|c|c|c|}
\hline \multirow{2}{*}{\multicolumn{2}{|c|}{ Perubahan }} & \multicolumn{2}{|c|}{ Harga Jual } & \multirow{2}{*}{ NPV } \\
\hline & & Type 36 & Type 54 & \\
\hline \multirow{3}{*}{ Harga Jual Awal } & & $\mathrm{Rp}$ & $\mathrm{Rp}$ & $\mathrm{Rp}$ \\
\hline & $0,00 \%$ & 120.500 .00 & 245.000 .00 & 5.854 .678 .69 \\
\hline & & 0 & 0 & 3 \\
\hline \multirow{3}{*}{$\begin{array}{c}\text { Harga Jual } \\
\text { Menurun } 10 \%\end{array}$} & & $\mathrm{Rp}$ & $\mathrm{Rp}$ & $\mathrm{Rp}$ \\
\hline & $1000 \%$ & 108.450 .00 & 220.500 .00 & 2.180 .928 .66 \\
\hline & $10,00 \%$ & 0 & 0 & 3 \\
\hline \multirow{3}{*}{$\begin{array}{c}\text { Harga Jual, } \\
\text { NPV Mendekati } \\
0\end{array}$} & & $\mathrm{Rp}$ & $\mathrm{Rp}$ & $\mathrm{Rp}$ \\
\hline & $15,87 \%$ & 101.998 .11 & 207.382 .05 & 0 \\
\hline & & 3 & 6 & \\
\hline Harga Jual & - & $\mathrm{Rp}$ & $\begin{array}{l}\text { Кр } \\
196.000 .00\end{array}$ & Rp1.535.524 \\
\hline Menurun $20 \%$ & $20,00 \%$ & 96.400 .000 & & $.185)$ \\
\hline
\end{tabular}

Sumber: Hasil Olahan Penulis

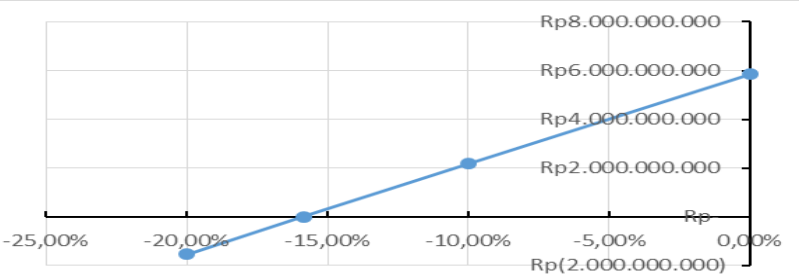

Gambar 3. Grafik Hubungan Perubahan Harga Jual Terhadap NPV (Sumber: Olahan Penulis)

Dari Tabel 12 dan Gambar 3 hubungan perubahan harga jual terhadap NPV, dapat diketahui batas penurunan harga jual Perumahan Kalianget Paradise yaitu sebesar $-15,87 \%$ dari harga jual awal.

4. Perubahan Tingkat Suku Bunga Pinjaman.

Bila besarnya suku bunga pinjaman awal diubah pada interval $\pm 200 \%$ maka nilai-nilai NPV akan menjadi sebagai berikut (Tabel 13):

Tabel 13.

Hubungan Harga Jual dengan NPV

\begin{tabular}{|c|c|c|c|c|}
\hline Perubahan & & Suku Bunga & & NPV \\
\hline Suku Bunga Dinaikkan & $200,00 \%$ & $31,05 \%$ & $\mathrm{Rp}$ & $(239.016 .280)$ \\
\hline NPV Mendekati 0 & $189,88 \%$ & $30,00 \%$ & $\mathrm{Rp}$ & $(14.472 .234)$ \\
\hline Suku Bunga Dinaikkan & $150,00 \%$ & $25,88 \%$ & $\mathrm{Rp}$ & 941.953 .765 \\
\hline Suku Bunga Awal & $0,00 \%$ & $10,35 \%$ & $\mathrm{Rp}$ & 5.854 .678 .693 \\
\hline
\end{tabular}

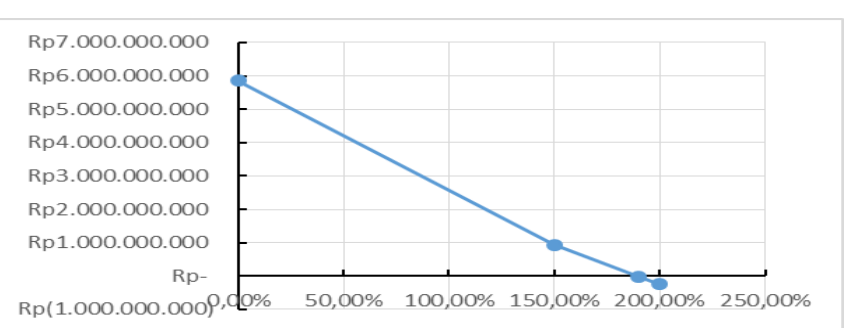

Gambar 4. Grafik Hubungan Perubahan Tingkat Suku Bunga Pinjaman Terhadap NPV (Sumber: Olahan Penulis)

Dari Tabel 13 dan Gambar 4 hubungan perubahan tingkat suku bunga pinjaman terhadap NPV, dapat diketahui batas kenaikan tingkat suku bunga pinjaman Perumahan Kalianget Paradise yaitu sebesar 183,10\% dari suku bunga pinjaman awal.

\section{KESIMPULAN}

Setelah dilakukan analisa aspek finansial yang telah diuraikan pada Bab IV, maka dapat diambil kesimpulan bahwa pembangunan Perumahan Kalianget Paradise yaitu layak dalam segi finansial. Dapat dilihat dari perolehan nilai: a. Net Present Value (NPV) yang bernilai positif sebesar Rp 5.854.679.693 (NPV>0).

b. Internal Rate of Return (IRR) diperoleh nilai $47,89 \%$ lebih besar dari pada arus pengembalian yang diinginkan sebesar $10,88 \%$ (IRR>MARR).

c. Payback Period (PP) pada tahun ke-3 bulan ke-2 lebih kecil dari masa investasi 6 tahun.

Dari hasil perhitungan analisa sensitifitas antara variabel biaya investasi, tingkat unit terjual (occupancy rate), harga jual, dan tingkat suku bunga terhadap NPV diketahui bahwa pembangunan Perumahan Kalianget Paradise dikatakan tidak layak jika:

a. Kenaikan biaya investasi lebih besar $22,43 \%$ dari biaya investasi awal yang telah ditetapkan.

b. Penurunan tingkat unit terjual (occupancy rate) lebih besar $18,87 \%$ dari tingkat unit terjual awal yang telah ditetapkan

c. Penurunan harga jual lebih besar $15,87 \%$ dari harga jual awal yang telah ditetapkan.

d. Kenaikan tingkat suku bunga pinjaman lebih besar $189,88 \%$ dari tingkat suku bunga awal yang telah ditetapkan.

\section{DAFTAR PUSTAKA}

[1] Kontributor Wikipedia, "Kabupaten Sumenep," 2017.

[2] M. Labombang, "Analisa Investasi Proyek Perumahan Taman Sidorejo Kabupaten Sidoarjo," J. SMARTek, vol. 5, no. 1, pp. 58-64, 2007.

[3] I. N. Pujawan, Ekonomi Teknik, 2nd ed. Surabaya: Guna Widya, 2009.

[4] R. Nufaili and C. Utomo, "Analisa Investasi Hotel Pesona Makasa," J. Tek. ITS, vol. 3, no. 2, pp. D143-D146, 2014.

[5] A. Prastiwi and C. Utomo, "Studi Kelayakan Investasi Perumahan Green Semanggi Mangrove Ditinjau Dari Aspek Finansial," J. Tek. ITS, vol. 2, no. 2, pp. D191-D196, 2013.

[6] M. A. Syahrizal and C. Utomo, "Analisa Pembeayaan Investasi Proyek Perumahan Green Pakis Regency Malang," J. Tek. ITS vol. 3, no. 2, pp. C67-C71, 2014. 
